\title{
Budaya Machismo dan Kekerasan Gender (Femicide) di El Salvador
}

\author{
Y. A. Wahyuddin ${ }^{1}$, Ambika Putri Swakartika Sari ${ }^{1}$ \\ ${ }^{1}$ Program Studi Hubungan Internasional, Universitas Mataram, NTB, Indonesia \\ ${ }^{1}$ Program Studi Hubungan Internasional, Universitas Mataram, NTB, Indonesia \\ aria_wahyuddin@unram.ac.id
}

\begin{abstract}
Violence against women in El Salvador -as known as the land of gangster has a significant escalation with the peak being femicide. This phenomenon indicates that unequal power relations between men and women further strengthen the culture of machismo in the patriarchal structure of society in El Salvador, so the "culture of violence" and "culture of silence" can be massively accepted. This culture of violence against women does not emerge without cause but has a long and structured historical root. The culture of masculinity that is deeply embedded in people's life in El Salvador and manifested in a machismo culture emphasizes how domination is owned by men over women. Women are considered as property rights and owners are free to treat their property according to their wishes, including in the form of violence. In addition to the deeply inherent patriarchal culture, a long history of civil war has also influenced acts of violence in people's lives in El Salvador and especially women and girls who become victims. Violence that occurs not only in the domestic sector but also in the public sector so that this places women in a position full of discrimination. The violence that occurs is actually carried out by the closest people, such as husbands, ex-husbands and boyfriends, resulting in insecurity for women.
\end{abstract}

Keyword: El Salvador, Femicide, Latin America, Machismo.

\begin{abstract}
ABSTRAK
Kekerasan terhadap perempuan di EI Salvador -sebagai negara dengan julukan the land of gangster memiliki eskalasi yang signifikan dengan puncaknya ialah femicide. Fenomena ini menandakan bahwa relasi kuasa yang tidak setara antara laki-laki dan perempuan semakin menguatkan budaya machismo dalam struktur masyarakat patriarkis di El Salvador, sehingga "budaya kekerasan" dan "budaya diam" dapat diterima secara masif. Budaya kekerasan terhadap perempuan ini tidak muncul tanpa sebab melainkan memiliki akar sejarah yang panjang dan terstruktur. Budaya maskulinitas yang sangat melekat dalam kehidupan masyarakat di El Salvador dan terwujud dalam budaya machismo mempertegas bagaimana dominasi yang dimiliki oleh kaum pria terhadap kaum perempuan. Perempuan seperti dianggap sebagai hak milik dan pemilik bebas untuk memperlakukan miliknya sesuai dengan kehendaknya termasuk yang berwujud kekerasan. Selain budaya patriarki yang sangat melekat tersebut, sejarah perang saudara yang panjang turut mempengaruhi tindakan kekerasan dalam kehidupan masyarakat di El Salvador dan terutama yang menjadi korban adalah perempuan dan anak perempuan. Kekerasan yang terjadi tidak hanya pada sektor domestik tetapi juga dalam sektor publik sehingga hal ini menempatkan perempuan pada posisi yang penuh dengan diskriminasi. Kekerasan yang terjadi justru dilakukan oleh orang-orang terdekat seperti suami, mantan suami, maupun pacar sehingga mengakibatkan ketidakamanan bagi perempuan.
\end{abstract}

Kata kunci: Amerika Latin, El Salvador, Femicide, Machismo.

\section{PENDAHULUAN}

Sejarah konflik dan perang yang panjang membawa dampak baik secara langsung maupun tidak langsung terhadap eskalasi kekerasan di El Salvador. Perang saudara yang terjadi pada akhir 70-an sampai dengan perang antar geng (gangster) mengakibatkan masyarakat sudah terbiasa dengan hal-hal yang berbau kekerasan dan brutalitas bahkan pembunuhan. Dinamika dalam kehidupan di El Salvador tersebut 
menyebabkan negara ini dikenal luas sebagai salah satu negara dari tiga negara yang dikenal dengan julukan The Northern Triangle atau wilayah segitiga di Amerika Latin bagian tengah dengan tingkat kriminalitas yang tinggi dan melintasi batas negara. Dari berbagai macam aksi kriminalitas dan kekerasan tersebut perempuan menjadi salah satu pihak yang menjadi korban. Aksi-aksi kekerasan yang mayoritas dilakukan oleh laki-laki dan ditambah dengan melekatnya budaya machismo yang lazim di kawasan ini, semakin memperparah diskriminasi bahkan pembunuhan di El Salvador. Hal tersebut menimbulkan ketidakamanan dan ketidaksetaraan dialami oleh perempuan bahkan anak perempuan di El Salvador.

Menurut Diana Russell, konsep femicide yang digaungkannya telah banyak digunakan di negara-negara Amerika Latin, berbeda dengan respon para feminist di negaranya pada saat itu yakni Amerika Serikat(Pinelo, 2015). Sejalan dengan pernyataan tersebut, banyak aktivis dan praktisi perempuan di Kawasan Amerika Latin yang turut menyumbangkan konsep mengenai fenomena ini, seperti aktivis Meksiko Marcela Legarde menerjemahkan femicide menjadi feminicidio ke dalam bahasa Spanyol dengan tujuan pembedaan makna dari apa yang diutarakan oleh Diana Russell. Legarde mengganggap bahwa femicide adalah sebuah kejahatan dengan atensi kebencian dari pembunuhan kepada perempuan yang mana dipicu oleh budaya machismo serta ideologi seksisme(Morales, 2020). Jika dilihat secara politis, femicide muncul sebagai alternatif mengenali dan memperlihatkan ketidaksetaraan serta kekerasan sistematis terhadap perempuan. Femicide juga berkontribusi mematahkan argumen bahwa kekerasan berbasis gender merupakan masalah privat dan personal karena nyatanya permasalahan ini berdimensi politik, sosial dan budaya(Gunadha, 2018).

Untuk memberikan legitimasi bagi penanganan fenomena tersebut, simposium tentang Femicide dilaksanakan pada tanggal 26 November 2012 di markas besar PBB di Wina, Austria. Simposium tersebut mengusung kesempatan di Hari Penghapusan Kekerasan Terhadap Perempuan Internasional setiap tanggal 25 November. Hasil penting dari simposium ini adalah Declaration of the Vienna Symposium on Femicide atau "Deklarasi Wina tentang Femisida".

Beberapa bentuk femicide yang menjadi perhatian diantaranya adalah, (1) Pembunuhan perempuan sebagai akibat dari kekerasan pasangan intim; (2) Penyiksaan dan pembunuhan misoginis terhadap perempuan; (3) Pembunuhan perempuan dan anak perempuan atas nama "kehormatan"; (4) Menargetkan pembunuhan perempuan dan anak perempuan dalam konteks konflik bersenjata; (5) Pembunuhan terkait mahar wanita; (6) Pembunuhan perempuan dan anak perempuan karena orientasi seksual dan identitas gender mereka; (7) Pembunuhan perempuan dan gadis asli dan pribumi karena jenis kelamin mereka; (8) Pembunuhan bayi perempuan dan pemilihan jenis kelamin berdasarkan jenis kelamin; (9) Kematian terkait mutilasi genital (Female Genital Mutilation/FGM); (10) Tuduhan sihir; dan (11) Pembunuhan berbasis gender lainnya yang berhubungan dengan geng, kejahatan terorganisir, pengedar narkoba, perdagangan manusia, dan proliferasi senjata kecil(United Nations Office on Drugs and Crimes, 2012).

Bentuk-bentuk femicide di atas jarang diselidiki dan dituntut dengan alasan karena kurangnya data dan analisis, kemudian alasan selanjutnya adalah fakta bahwa sebagian besar kejahatan tersebut terjadi dalam konteks domestik atau ranah privat. 
Artinya, kekerasan terhadap perempuan dan anak perempuan mayoritas dilakukan oleh orang terdekat dimana menjadi kejahatan yang terkonstruksi dan telah melekat dalam budaya yang menjadikannya sebagai sesuatu yang lumrah.

Femicide juga masuk ke dalam salah satu bentuk kejahatan terhadap kemanusiaan jika melihat aspek penghilangan nyawa seseorang. Bentuk kejahatan terhadap kemanusiaan yang ditetapkan Rome Status of the International Criminal Court tahun 1998 mencakup (a) pembunuhan; (b) pembasmian; (c) perbudakan; (d) pemindahan penduduk secara paksa; (e) pemenjaraan atau perampasan kebebasan fisik yang melanggar aturan dasar hukum internasional; (f) penyiksaan; (g) pemerkosaan, perbudakan seksual, prostitusi paksa, kehamilan paksa, sterilisasi paksa, atau bentuk lain kekerasan seksual yang sebanding; (h) penganiayaan terhadap kelompok berdasarkan gender, ras, nasional, etnis, budaya, agama; (i) penghilangan orang secara paksa; (j) kejahatan apartheid; (k) tindakan tidak manusiawi lain yang menyebabkan penderitaan yang hebat, atau luka serius terhadap tubuh atau mental atau kesehatan fisik(Ashari, 2015, p. 134). Ketetapan di atas disebut sebagai crimes against humanity yaitu tindak kejahatan serius yang merendahkan harkat dan martabat manusia dimana pembunuhan yang dimaksudkan lebih general dan netral gender.

Femicide merupakan muara atau puncak dari segala bentuk ketertindasan, ketimpangan dan ketidakadilan yang dialami penyintas (perempuan) dan dilakukan oleh laki-laki dengan relasi gender tertentu. Maka dari itu, konsep femicide berpotensi untuk dikodifikasikan di dalam Pengadilan Pidana Internasional (International Criminal Court [ICC])(Pinelo, 2015, p. 90). Namun, pemaknaan akan fenomena ini perlu dikontekstualisasikan sesuai dengan budaya di suatu masyarakat. Beberapa manifestasi dari femicide telah diidentifikasi dari kasus-kasus yang banyak terjadi di Amerika Latin.

Hal tersebut ditunjang oleh Deklarasi Femicide yang menerangkan bahwa Kawasan Latin Amerika dan Karibia adalah manifestasi serius dari diskriminasi dan kekerasan terhadap perempuan. Bersumber dari interpretasi di atas mengenai manifestasi bentuk dan jenis dari femicide, dalam tulisan ini akan mengelaborasikan ke dalam studi kasus di salah satu negara di Kawasan Amerika Latin dan Karibia yaitu El Salvador. Tulisan ini mencoba untuk menjelaskan bagaimana akar kekerasan terhadap wanita (femicide) di El Salvador serta bagaimana upaya yang dilakukan oleh pemerintahnya untuk meminimalisir kasus tersebut? Tulisan ini akan melihat kasus tersebut dengan menggunakan pendekatan kekerasan kultural oleh Johan Galtung.

\section{TINJAUAN PUSTAKA}

Penelitian mengenai tindakan kekerasan di Amerika Latin sudah cukup banyak dilakukan oleh para peneliti dengan meninjau dari berbagai macam aspek. Maria De Jesus dan Carissa Hernandes dalam tulisannya yang berjudul Generalized Violence as a Threat to Health and Well-Being: A Qualitative Study of Youth Living in Urban Settings in Central America's "Northern Triangle" dalam International Journal of Environmental Research and Public Health pada tahun 2019 dengan melakukan wawancara kepada anak-anak muda di kawasan yang dikenal dengan sebutan The Northern Triangle yaitu El Salvador, Guatemala dan Honduras terkait dengan eskalasi kekerasan di kawasan tersebut(De Jesus \& Hernandes, 2019). Kedua peneliti ini 
melihat bagaimana kekerasan yang kerap terjadi sehari-hari memiliki implikasi terhadap kesehatan dan keamanan manusia bagi anak-anak muda di kawasan ini.

Mereka juga melihat bagaimana perang saudara yang terjadi dalam waktu yang cukup lama berakibat langsung pada tumbuhnya budaya kekerasan di kawasan Northern Triangle, ditambah lagi pasca perang saudara tersebut kawasan ini seperti menjadi ladang yang subur bagi bertumbuhnya gangster yang membawa dampak langsung bagi tindakan kekerasan dan kesejahteraan bagi anak-anak mudanya. Kekerasan dikonseptualisasikan sebagai fenomena sistemik yang dihasilkan dan direproduksi melalui interaksi kompleks ketidakadilan struktural dan hubungan kekuasaan yang tidak setara. Kedua peniliti ini mengidentifikasikan dua meta-tema dalam penelitiannya yaitu: pertama, 'Lack of health' yang didefinisikan sebagai 'tidak didapatkannya perasaan damai dalam kehidupan baik itu dalam keluarga, komunitas, maupun negara'.

Tabel 1. Meta-Tema 'Lack of Health'

\section{Table 1}

An overview of descriptive subthemes (first-level thematic analysis), thematic clusters (secondlevel thematic analysis) and first meta-theme (third-level thematic analysis).

\begin{tabular}{|c|c|c|c|}
\hline \multicolumn{4}{|c|}{$\begin{array}{l}\text { Meta-Theme 1: Lack of Health, Defined as not Experiencing Peace within the Family, the Community, and } \\
\text { the Country }\end{array}$} \\
\hline $\begin{array}{c}\text { Thematic Clusters: } \\
\text { Violence as a Common } \\
\text { Occurrence }\end{array}$ & $\begin{array}{l}\text { Living in Fear and } \\
\text { Insecurity }\end{array}$ & Victimization & $\begin{array}{c}\text { Lack of State } \\
\text { Protection and Services }\end{array}$ \\
\hline $\begin{array}{c}\text {-Massacred bodies on the } \\
\text { streets }\end{array}$ & -Something bad will happen & & $\begin{array}{l}\text {-No security from the } \\
\text { state and the police }\end{array}$ \\
\hline $\begin{array}{l}\text {-Rival gangs kill each other } \\
\text { and other victims }\end{array}$ & $\begin{array}{l}\text { - Scared to go anywhere } \\
\text { especially outside my }\end{array}$ & $\begin{array}{c}\text {-Getting extorted and } \\
\text { threatened by gang } \\
\text { members }\end{array}$ & $\begin{array}{c}\text {-No health and social } \\
\text { services }\end{array}$ \\
\hline -Police-gang killings & $\begin{array}{l}\text { especiany outside my } \\
\text { neighborhood }\end{array}$ & -Getting robbed is the & $\begin{array}{l}\text {-Fragmented families } \\
\text { and children are on their }\end{array}$ \\
\hline $\begin{array}{c}\text {-Girls and women disappeared } \\
\text { or are recruited by gang } \\
\text { members }\end{array}$ & $\begin{array}{c}\text {-Culture of silence, mistrust, } \\
\text { and fear }\end{array}$ & norm & $\begin{array}{l}\text { own } \\
\text {-Children ripe for } \\
\text { recruitment }\end{array}$ \\
\hline
\end{tabular}

Sumber: (De Jesus \& Hernandes, 2019)

Dalam wawancara yang kedua peneliti ini lakukan, para narasumber dalam kelompok diskusi berbicara tentang bagaimana kekerasan yang terjadi sehari-harinya dan juga pentingnya untuk memahami bagaimana efek multi-levelnya pada kesehatan dan kesejahteraan secara keseluruhan. Salah seorang peserta dalam diskusi tersebut memberikan pernyataan, yaitu "kami mengalami dan melihat kekerasan di mana-mana. Kesehatan tidak hanya berkaitan dengan apa yang terjadi dengan individu dalam hal 
masalah kesehatan psikologis atau fisik. Kesehatan juga mencakup apa yang terjadi di tingkat keluarga, komunitas, dan negara. Kesehatan berarti mengalami kedamaian dalam keluarga kita, komunitas kita, dan negara kita. Kesehatan adalah kedamaian dan kesejahteraan secara keseluruhan. Kami tidak mengalami kesehatan di sini"(De Jesus \& Hernandes, 2019).

Kemudian meta-tema kedua yang diidentifikasi oleh kedua peneliti ini adalah 'resilience'. Semua peserta FGD dan narasumber menggambarkan ketahanan, seperti tetap optimis tentang masa depan, komitmen terhadap pendidikan, pentingnya dukungan sosial dan keuangan dari anggota keluarga, serta keterlibatan mereka dengan kelompok remaja di masyarakat. Semua peserta mengungkapkan rasa kewajiban yang kuat untuk bekerja dengan baik, terutama mengingat bahwa anggota keluarga mereka di AS dan di negara tersebut menawarkan dukungan dan pengorbanan finansial dan emosional agar mereka berhasil. Franci, peserta kelompok fokus dari Tegucigalpa, menyatakan: "Ibu saya yang berada di Maryland mengirimkan uang setiap bulan untuk membantu kami. Dia memberi saya banyak dukungan dan kakak perempuan saya di sini juga. Saya akan berhasil. Keluarga saya membuat pengorbanan terakhir untuk saya dan saya perlu memastikan saya berhasil sehingga pengorbanan mereka sepadan. Saya ingin ibu saya bangga dengan putranya yang ada di sini".

Tabel 2. Meta-Tema 'Resilience'

\section{Table 2}

An overview of descriptive subthemes (first-level thematic analysis), thematic clusters (secondlevel thematic analysis) and second meta-theme (third-level thematic analysis).

\begin{tabular}{ccc}
\hline & \multicolumn{2}{c}{ Meta-Theme 2: Resilience } \\
\hline $\begin{array}{c}\text { Thematic Clusters: } \\
\text { Positive Future } \\
\text { Outlook and } \\
\begin{array}{c}\text { Commitment to } \\
\text { Education }\end{array}\end{array}$ & $\begin{array}{c}\text { Transnational and Local Family Network } \\
\text { Support }\end{array}$ & $\begin{array}{c}\text { Engagement in Community-Based } \\
\text { Youth Groups }\end{array}$ \\
\hline $\begin{array}{c}\text {-I want to do well in } \\
\text { school to have a good } \\
\text { future }\end{array}$ & - Family members here and in the United States & -By actively participating in the youth \\
& offer me social and emotional support & group, I feel like I am contributing to \\
-I want my country to & my community \\
progress & financial support for school expenses and for & -I get social support from my peers in \\
our family needs here & the youth group \\
\hline
\end{tabular}

Sumber: (De Jesus \& Hernandes, 2019)

Tulisan lain yang membahas mengenai kasis femicide adalah artikel jurnal yang berjudul No More Killings! Women Respond to Femicides in Central America dalam Gender and Development, Vol. 15, No. 1, Gender-Based Violence (Mar., 2007) yang ditulis oleh Marina Prieto-Carrón, Marilyn Thomson and Mandy Macdonald(Prieto- 
Carrón et al., 2007). Artikel ini membahas bentuk khusus kekerasan sosial atau pembunuhan dengan kekerasan terhadap perempuan di Meksiko dan Amerika Tengah. Sifat femisida dengan menganalisis situasi dari perspektif gender, sebagai bentuk ekstrim dari kekerasan berbasis gender (gender-based violence (GBV)), yang kemudian menghubungkan femisida dengan diskriminasi, kemiskinan dan 'reaksi' terhadap perempuan dieksplorasi dalam tulisan ini. Dalam iklim impunitas negara total, sangat penting untuk mendukung respon para feminis dan organisasi perempuan di wilayah yang melakukan penelitian untuk mendokumentasikan femisida dan GBV secara umum, mendukung survivor dan keluarganya, serta melakukan kegiatan advokasi.

Menurut Garwood (2002) dan Erturik (2005) dalam Prieto-Carrón et.al (2007), laporan mulai muncul di media tentang penemuan mayat yang dimutilasi dan juga perempuan yang diperkosa dan dibunuh di tempat pembuangan sampah di luar kota pada tahun 1993 di Ciudad Juairez di perbatasan Meksiko-AS(Garwood 2002; Ertuirk 2005). Menurut Clulow (2005) dan Thomson (2006) dalam tulisan yang sama, femisida di seluruh Amerika Tengah telah mencapai pada proporsi yang mengkhawatirkan. Menurut laporan Amnesty International yang diterbitkan pada tahun 2006, di Guatemala, misalnya, lebih dari 2.200 wanita telah dilaporkan dibunuh sejak 2001. Faktanya, para peneliti feminis yang melakukan studi regional untuk membandingkan tren di berbagai negara telah menemukan bahwa di Guatemala, El Salvador, Honduras, Nikaragua, dan Kosta Rika, jika digabungkan, setidaknya seribu wanita meninggal setiap tahun akibat femisida atau dalam bentuk kekerasan berbasis gender lainnya(Prieto-Carrón et al., 2007, p. 25).

Dalam tulisan yang sama, asosiasi kerabat dan orang yang selamat di Guatemala atau Fundación Sobrevivientes, melaporkan pembunuhan kejam terhadap Maria Isabel Veliz Franco, yang ditemukan tewas pada Desember 2001. Maria Isabel, seorang siswa berusia 15 tahun yang bekerja di sebuah toko, diperkosa dan tersiksa; tubuhnya ditemukan di dalam tas, diikat dengan kawat berduri, wajahnya rusak dan kukunya robek. Kemudian menurut Kennedy (2005), kejahatan serupa juga dilaporkan di tempat lain di wilayah tersebut. Misalnya, di Honduras, tubuh perempuan yang telanjang dan disiksa ditemukan dengan kaki terbuka sebagai demonstrasi kekuatan laki-laki; dan dua wanita muda ditemukan tewas dengan pesan kepada mantan calon presiden tertulis di tubuh mereka, memperingatkan dia untuk tidak melakukan kampanye melawan geng kriminal (dikenal sebagai maras atau pandillas)(PrietoCarrón et al., 2007).

Femicide di Amerika Tengah dan Meksiko adalah ekspresi diskriminasi gender dan hubungan kekuasaan yang tidak setara antara pria dan wanita, yang beroperasi di ranah privat dan publik. Sementara pembunuhan, penyiksaan dan mutilasi individu perempuan oleh penyerang laki-laki membuat diskriminasi gender sangat terlihat, diskriminasi yang dilembagakan terbukti dalam kegagalan pemerintah untuk menyelidiki pembunuhan ini secara khusus dan untuk melindungi hak-hak perempuan secara umum. Ini bukan hanya masalah sosial tetapi juga masalah keamanan. Negara dan lembaganya, dengan tidak memiliki kemauan politik untuk menghadapi femisida, sebenarnya telah mendorong reproduksinya.

Upaya advokasi organisasi perempuan perlu dan harus mendapatkan dukungan dalam semua tingkatan. Dukungan internasional diperlukan, melalui jaringan 
dan kolaborasi yang berbeda, seperti proyek antara CAWN di London dan CEM-H di Honduras. Organisasi perempuan lebih dekat dengan perempuan korban kekerasan dan realitas mereka. Bersama dengan para pendukung feminis, mereka telah mengembangkan kerangka analisis yang menempatkan femisida sebagai bagian dari kontinum kekerasan berbasis gender di semua aspek kehidupan perempuan, manifestasi paling ekstrim dari banyak jenis kekerasan lainnya bahwa wanita menderita.

Dalam artikel ini juga menjelaskan mengenai perlunya lembaga donor internasional untuk mengambil sikap untuk menghadapi kekerasan berbasis gender, karena kekerasan itu ada dalam semua proses sosial yang coba ditangani oleh program mereka. Distribusi dana yang lebih besar untuk program yang mempromosikan kesetaraan gender akan menjadi titik awal. Berkenaan dengan Amerika Tengah, tekanan diperlukan untuk menghentikan impunitas pemerintah. Misalnya, perjanjian kerja sama antara Uni Eropa dan negara-negara di kawasan ini harus memasukkan syarat bahwa pemerintah mengambil tindakan untuk menyelesaikan kejahatan terhadap perempuan. Selama komunitas internasional mengabaikan kekerasan terhadap perempuan di Amerika Tengah, kecil harapan untuk menghentikan pembunuhan perempuan. Wanita di Amerika Tengah pantas mendapatkan dukungan internasional.

\section{METODE PENELITIAN}

Artikel ini menggunakan jenis penelitian eksplanatif kualitatif. Adapun tahaptahap yang dilakukan dalam penelitian ini yaitu pengumpulan data, analisis data dan pengambilan kesimpulan. Tahap pertama penelitian ini dimulai dengan pengumpulan data sekunder dari berbagai literatur di jurnal, hasil penelitian, dan sumber lainnya dari media cetak maupun elektronik yang berkaitan dengan objek penelitian. Tahap kedua adalah melakukan tinjauan atas literatur tersebut, kemudian melakukan analisis data untuk menarik pola dan menemukan tren dari berbagai literatur.

\section{KERANGKA PEMIKIRAN}

\section{KEKERASAN KULTURAL GALTUNG}

Pemikiran Galtung terkait kekerasan berkontribusi terhadap gerakan kaum feminis dalam upaya menumbuhkan kesadaran akan adanya kekerasan, penindasan dan ketidakadilan terhadap perempuan. Isu kekerasan menjadi penting karena selama ini, kekerasan yang menimpa perempuan berupa penyiksaan, pemerkosaan, kekerasan domestik, pelecehan seksual, bahkan hingga pembunuhan merupakan mekanisme yang memproduksi subordinasi perempuan oleh laki-laki(Eriyanti, 2017, p. 28). Gagasan gender sebagai konstruksi sosial menjadi salah satu unsur yang mewujudkan hubungan kekuasaan di masyarakat. Lebih jauh, pemahaman tentang gender yang patriarkis bisa menjadi kunci untuk produksi dan reproduksi kekerasan di semua tingkatan.

Kekuasaan yang menghancurkan martabat manusia inilah yang menjadi sebuah proses kekerasan(Windhu, 1992, p. 60), terlebih jika memiliki relasi dengan gender yang disebut sebagai kekerasan berbasis gender. Bahkan, hal tersebut bisa terjadi dalam situasi tidak ada perang dan lebih banyak lagi dalam situasi perang atau 
konflik. Kekerasan berbasis gender, yang korbannya mayoritas adalah perempuan muncul dalam wujud yang beragam dimana puncak kekerasan terhadap perempuan yang berakhir dengan kematian dikenal sebagai femicide.

Dalam melihat fenomena kekerasan pada perempuan yang akhirnya bermuara pada femicide akan dielaborasi dengan Trilogi Kekerasan Galtung yaitu Kekerasan Langsung (antara Pelaku-Korban), Kekerasan Struktural (yang bersumber dari struktur sosial (antar orang, masyarakat, kumpulan masyarakat (aliansi, daerah), dan (dibalik keduanya) Kekerasan Kultural (simbolis dalam agama, ideologi, bahasa, seni, pengetahuan, hukum, media, pendidikan; gunanya melegitimasi Kekerasan Langsung dan Kekerasan Struktural). Kekerasan kultural dan kekerasan struktural menyebabkan kekerasan langsung. Kekerasan langsung juga menguatkan/memperburuk kekerasan struktural dan kekerasan kultural. Kekerasan langsung berupa fisik atau verbal tampil sebagai prilaku yang tidak berubah, karena akarnya adalah struktur dan budaya. Kekerasan Langsung adalah peristiwa; Kekerasan Struktural adalah proses; Kekerasan Kultural adalah yang permanen pada keduanya. Rangkaian kekerasan tersebut dapat dilihat dalam hubungan sebab-akibat (Kultural via Struktural via Langsung)(Makarim, 2012, p. 12).

Pada umumnya, aliran sebab akibat dari kultural via struktural ke kekerasan langsung dapat diidentifikasi. Kultur ini menceramahi, mengajari, menegur, menghasut dan mengumpulkan kita dalam melihat eksploitasi dan/atau represi sebagai suatu hal yang normal dan natural, atau untuk tidak melihatnya (khususnya sebagai eksploitasi) sama sekali. Kemudian terjadilah letusan-letusan, upaya-upaya untuk menggunakan kekerasan langsung untuk keluar dari sangkar besi struktural, dan kekerasan balasan (counter-violence) untuk menjaga keutuhan sangkar ini. Biasanya, aktivitas kriminal reguler sebagian merupakan suatu upaya oleh sang underdog untuk 'keluar' guna meredistribusikan kekayaan, menyeimbangkan, membalas dendam, atau oleh seseorang untuk tetap atau menjadi seorang topdog, dengan menguasai apa yang berharga dari struktur ini.

Kedua kekerasan ini, baik langsung maupun struktural, menimbulkan defisit kebutuhan. Ketika hal ini tiba-tiba terjadi maka kita dapat berbicara mengenai trauma. Ketika terjadi dalam suatu kelompok atau kolektivitas, kita memiliki trauma kolektif dan menjadi unsur penting bagi proses-proses dan peristiwa-peristiwa historis utama. Hal sederhana yang menjadi asumsinya adalah bahwa 'kekerasan menghasilkan kekerasan'. Kekerasan merupakan perampasan kebutuhan; perampasan kebutuhan merupakan suatu hal yang serius; salah satu reaksinya adalah kekerasan langsung. Reaksi lain yang muncul juga adalah perasaan kehilangan harapan, suatu sindrom kehilangan/frustasi yang muncul dari dalam sebagai sebuah agresi yang yang ditujukan pada diri sendiri maupun dari luar sebagai sebuah kelesuan dan penarikan(Galtung, 1996, p. 439).

Trilogi Kekerasan Galtung tersebut digambarkan sebagai suatu gerigi mesin yang saling berkaitan satu sama lainnya dan memiliki hubungan timbal balik serta aksireaksi yang saling berkaitan antara satu dengan yang lainnya. Dalam konteks EI Salvador kekerasan dalam teori Galtung ini memiliki keterkaitan antara satu dengan yang lainnya. Misalnya dalam kekerasan langsung 95\% kasus dilakukan oleh laki-laki dengan korbannya adalah perempuan. Kekerasan yang dilakukan "one on one" antara laki-laki dan perempuan terjadi secara masif pada semua tingkatan sosial, baik dari 
keluarga hingga masyarakat. Meskipun perempuan seringkali menjadi korban kekerasan yang dilakukan oleh laki-laki, dengan adanya struktur dan kultur pro kekerasan di masyarakat, perempuan sendiri akhirnya merasa kekerasan sebagai sesuatu hal yang tidak bisa dihindari(Eriyanti, 2017, p. 30).

Oleh karenanya, femicide menjadi isu krusial yang menjadi diskursus masyarakat dunia yang berusaha mencapai SDGs pada tahun 2030 dimana kesetaraan gender dan penghapusan kekerasan terhadap perempuan juga dilakukan secara masif dan komprehensif. Bahkan, di El Salvador sendiri, eskalasi kekerasan langsung terus meningkat sejak perang saudara yang menyebabkan bermunculannya gangster yang kini sudah menjadi kejahatan transnasional. Kemudian, homicide menjadi tren seiring dengan tingginya geng El Salvador dan pastinya berdampak pula terhadap femicide, sehingga masih terus berlangsung karena adanya budaya machismo masyarakat EI Salvador terutama laki-laki sejak mereka dilahirkan(Viceland, 2016).

Dengan konsepsi kekerasan struktural dan kekerasan kultural Johan Galtung, patriarki bisa dilihat sebagai penyebab utama terjadinya kekerasan(Eriyanti, 2017, p. 33). Patriarki menempatkan laki-laki dengan maskulinitasnya pada posisi dominan machismo culture atau maskulinitas yang berlebihan di El Salvador merupakan hal yang biasa dan wajar terjadi -dan perempuan dengan femininitasnya dalam posisi subordinat. Posisi laki-laki yang selalu dominan menjadikan kekerasan langsung yang dilakukan seperti femicide lumrah dilakukan di EI Salvador. Kekerasan kultural ini membuat kekerasan langsung dan struktural terlihat sebagai sesuatu benar atau setidaknya tidak salah(Galtung, 1996, p. 430). Bahkan, jika perempuan El Salvador melaporkan diri atas tindak kekerasan yang dialaminya, bandul kebenaran tidak ditindaklanjuti secara langsung melainkan respon yang kurang berpihak pada korban yaitu perempuan. Kemudian, Galtung juga membuat kategori-kategori kekerasan khusus untuk kasus kekerasan struktural yang bersifat ekstrem, yaitu (Makarim, 2012, p. 12):

1. Ecocide: kekerasan ekstrem terhadap alam;

2. Suicide: kekerasan langsung dan mematikan terhadap diri;

3. Homicide: kekerasan langsung dan mematikan terhadap orang lain;

4. Genocide: kekerasan langsung dan mematikan terhadap seluruh rakyat;

5. Structurocide: penghancuran struktur/destrukturisasi;

6. Culturocide: penghancuran budaya/dekulturisasi;

7. Omnicide: semua kekerasan yang disebutkan di atas.

Galtung dengan gagasannya mengenai "Trilogi Kekerasan" berupaya mengintegrasikan pendekatan feminisme dalam menjawab segala permasalahan mengenai kekerasan berbasis gender. Walaupun, gender hanya menjadi salah satu variabel dalam analisis kekerasan akan tetapi berhasil mengubah cara pandang dunia mengenai budaya patriarki khususnya machismo yang mewabah di El Salvador. Budaya machismo atau maskulinitas yang berlebihan harus bisa diimbangi dengan pemahaman adil gender agar fenomena femicide dapat berkurang hingga titik nol. 


\section{HASIL DAN PEMBAHASAN}

\section{SISTEM PATRIARKI DAN BUDAYA MACHISMO DI EL SALVADOR}

Patriarki merupakan sistem dalam kehidupan masyarakat yang mengutamakan garis kekuasaan laki-laki dengan menempatkannya pada posisi sebagai pemimpin dalam keluarga. Patriarki menjadi sebuah sistem struktur sosial dimana laki-laki mendominasi, menindas dan mengeksploitasi perempuan. Kekerasan terhadap perempuan terjadi karena adanya dominasi budaya patriarki dalam kehidupan masyarakat yang diskriminatif dan subordinatif dan berjalan beriringan dengan relasi kuasa yang timpang antara laki-laki dan perempuan, suami dan istri, orangtua dan anak, negara dan rakyat, guru dan murid, serta atasan dan bawahan. Relasi kuasa yang tidak seimbang dan setara antara laki-laki dan perempuan inilah yang menjadi penentu bagi objektifikasi dan stigmatisasi yang dialami oleh perempuan. Hal-hal tersebut tentu saja membawa dampak terhadap terjadinya tindakan-tindakan kekerasan terhadap perempuan dan anak perempuan menjadi lumrah dilakukan dan semakin diperparah dengan pengabaian oleh masyarakat dan bahkan aktor negara dalam sistem patriarki.

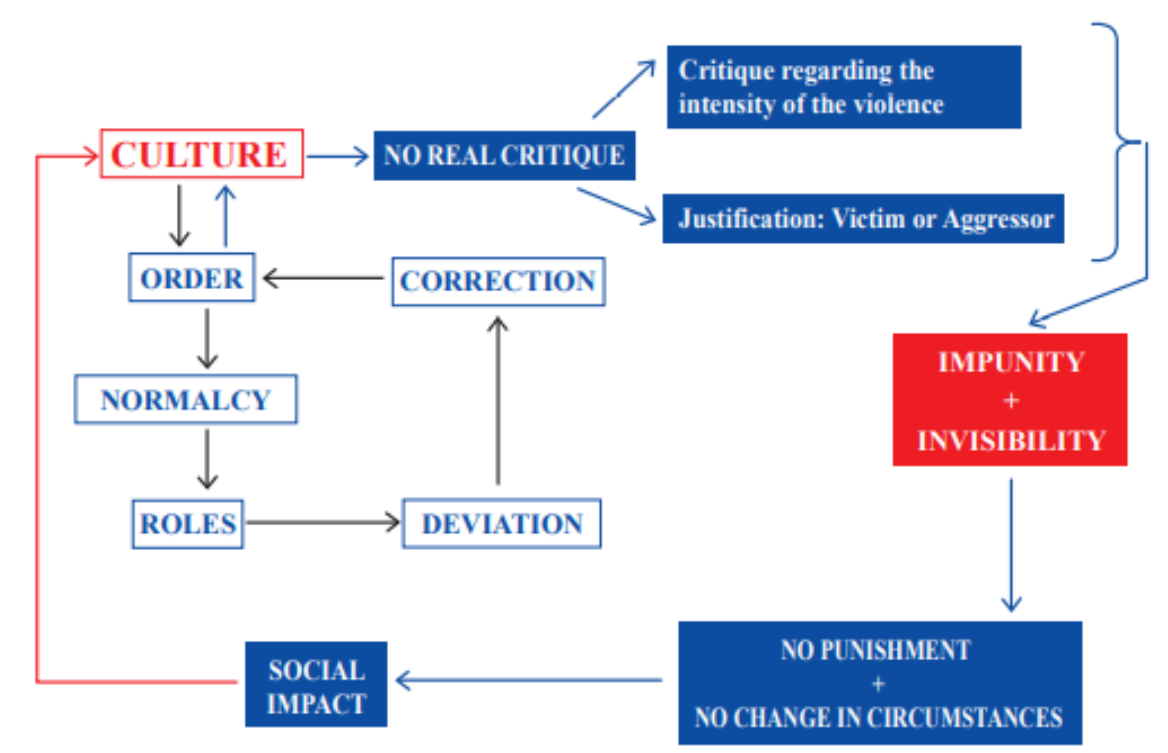

Gambar 1. Normalisasi Kekerasan terhadap Perempuan (Roth \& Villa, 2012, p. 40)

Siklus tersebut terus berulang karena adanya impunitas atau keadaan dimana para pelaku tidak dapat dipidanakan -nirpidana. Kasus tersebut semakin diperparah dengan sifat lembaga peradilan yang cenderung tertutup dan tidak terbuka dalam menyampaikan informasinya kepada masyarakat luas sehingga hal ini menyebabkan hukum yang ada tidak mampu merubah keadaan menyulitkan bagi kaum perempuan ini. Kemudian permasalahan ini menimbulkan dampak sosial yang lalu menjadi "budaya" karena terus menerus sehingga kekerasan terhadap perempuan ini tidak mendapat perhatian yang lebih dan tidak ada dasar legitimasi yang kuat untuk mengubahnya. 
Machismo dapat dikatakan sebagai sebuah bentuk hegemoni atau sifat maskulinitas yang berlebihan pada laki-laki dan membawa dampak kepada penguasaan yang berlebihan terhadap kehidupan perempuan - baik dalam bentuk pemikiran, pilihan, maupun tindakan perempuan, oleh laki-laki. Adapun yang menjadi tujuan dari tindakan ini adalah untuk menciptakan kepatuhan dengan kesadaran oleh perempuan bahwa laki-laki telah menguasainya sehingga seringkali perempuan bukan dijadikan sebagai subjek yang aktif melainkan hanya sebagai objek yang pasif. Machismo pada awalnya digambarkan sebagai bentuk sifat laki-laki yang peduli, bertanggungjawab, pengambil keputusan, memiliki karakter yang kuat dan bertugas sebagai pelindung dalam keluarga. Namun ketika machismo diasosiasikan dengan budaya Amerika Latin pandangan tersebut berubah dan lebih menunjukkan sesuatu yang lebih negatif, misalnya seperti "dominasi laki-laki", tindakan agresif, patriarki, autoritarianisme dan cenderung melakukan kekerasan karena mengutamakan kekuatan fisik.

Laki-laki yang dengan gigih mempertahankan ideologi maskulin tradisional atau machismo memiliki kemungkinan yang lebih tinggi melakukan tindakan kejam secara fisik atau psikologis kepada perempuan serta sama besarnya dengan keinginan mereka untuk tetap mempertahankan sikap yang cenderung mendorong untuk tindakan pelecehan seksual kepada perempuan. Machismo juga membentuk "budaya diam" atau culture of silence menjadi tertanam di dalam pemikiran para perempuan yang kemudian menempatkan mereka sebagai makhluk yang dianggap lemah. Oleh karena itu, machismo dan patriarki yang merupakan sebuah ide atau gagasan (ideologi) yang tak kasat mata -hanya berada dalam alam pikiran namun dapat memengaruhi tindakan, dianggap telah membudaya karena adanya "siklus pembenaran" dalam tindakan masyarakat. Kedua hal tersebut memiliki kontribusi yang cukup signifikan terhadap aksi-aksi yang lebih tendensius. Hal ini mengakibatkan insecurity (ketidakamanan) dan inequality (ketidaksetaraan) semakin meningkat seiring dengan kekerasan yang terjadi terhadap perempuan -yang pada akhirnya bermuara pada femicide.

Dalam Declaration of the Vienna Symposium on Femicide yang dilaksanakan pada bulan November 2012 dijelaskan bahwa femicide merupakan pembunuhan terhadap perempuan dan anak perempuan karena jenis kelaminnya, yang dapat berupa, antara lain: pembunuhan perempuan akibat kekerasan pasangan intim; penyiksaan dan pembunuhan misoginis terhadap wanita; pembunuhan wanita dan anak perempuan atas nama "kehormatan"; pembunuhan terarah terhadap wanita dan anak perempuan dalam konteks konflik bersenjata; pembunuhan wanita terkait mahar; pembunuhan perempuan dan anak perempuan karena orientasi seksual dan identitas gender mereka; pembunuhan perempuan dan anak perempuan penduduk asli dan pribumi karena jenis kelamin mereka; pembunuhan bayi perempuan dan pembunuhan janin berdasarkan jenis kelamin; kematian terkait mutilasi genital; tuduhan sihir; dan femicide lain yang berhubungan dengan geng, kejahatan terorganisir, pengedar narkoba, perdagangan manusia dan penyebaran senjata api ringan.

Sejarah perang saudara yang panjang dari El Salvador mengakibatkan negara ini mereproduksi budaya kekerasan terhadap perempuan sehingga melekat dalam kehidupan sehari-hari dibenak setiap masyarakatnya. Budaya machismo ini bahkan turut disertai dengan karakteristik misogini yaitu perasaan kebencian terhadap 
perempuan atau kepercayaan bahwa laki-laki lebih baik daripada perempuan. Menurut investigasi yang dilakukan oleh Viceland, dalam banyak kehidupan rumah tangga di EI Salvador, perempuan sudah terbiasa untuk menerima pukulan, dihajar, diperkosa karena mereka tidak mempunyai keberanian untuk pergi atau lari dari kondisi tersebut.

Hal ini merupakan sesuatu yang normal di El Salvador dan Amerika Latin pada umumnya. Karena, laki-laki sudah sejak dilahirkan menjadi machistas (penganut machismo) dan bukan karena keinginan mereka (laki-laki) dibesarkan seperti itu melainkan karena budaya yang sudah melekat tersebut. Pada akhirnya kondisi ini menjadi pemantik bagi munculnya berbagai macam tindakan kekerasan terhadap perempuan di El Salvador. Femicide ini menurut Russell dan Radford pembunuhan yang bernuansa misogini ini terjadi hampir di seluruh struktur lapisan masyarakat yang menganut sistem patriarkal namun dengan beragam manifestasi yang berbeda-beda (Radford \& Russell, 1992, pp. 2-3), sehingga konsep femicide/feminicide ini terdapat dalam segala kompleksitas tentang gagasan patriarki dimana perempuan hanya dianggap sebagai objek transaksional sehingga dianggap logis bagi para laki-laki untuk dieksploitasi dan dapat dibunuh.

\section{Grafik 1. Tingkat Homicide di Amerika Latin per 100,000 Populasi}

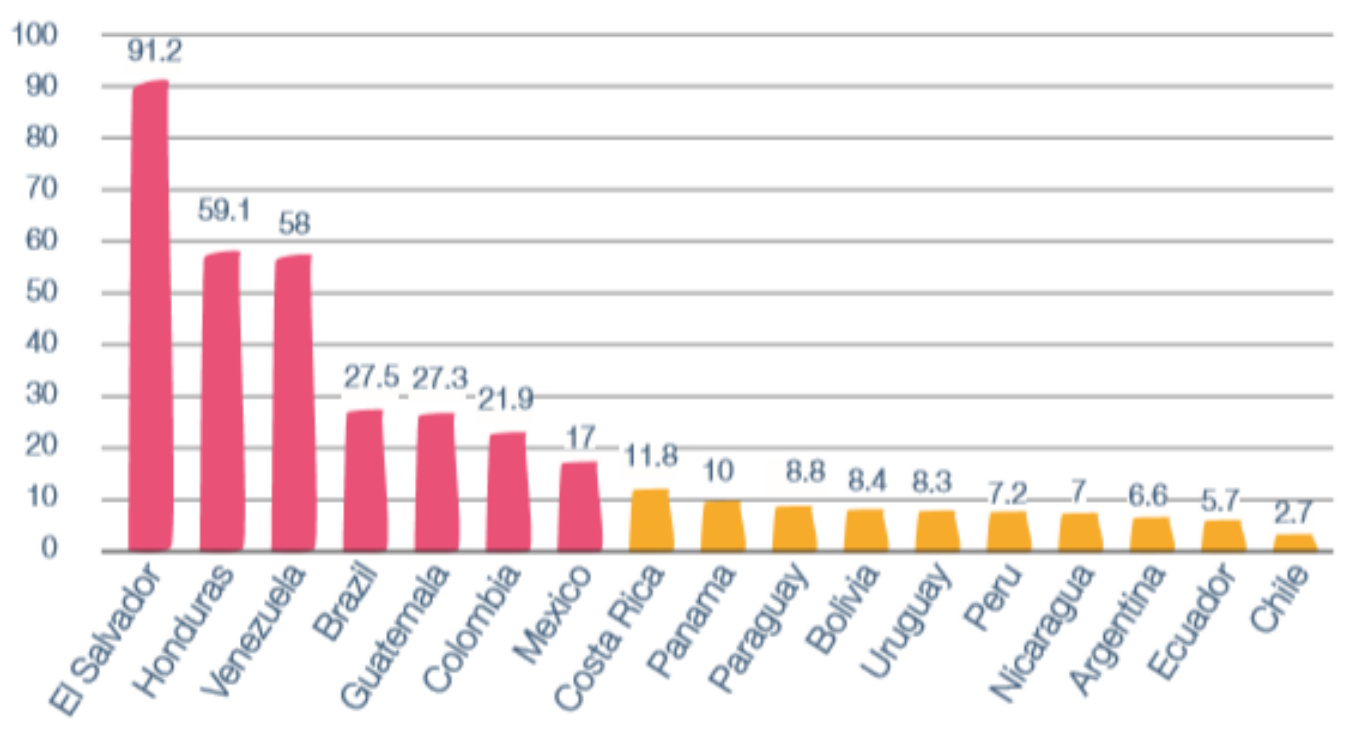

Sumber: (Igarapé Institute, 2017, p. 2)

El Salvador merupakan negara dengan tingkat femicide tertinggi di dunia, juga dengan catatan hak asasi manusia yang buruk dalam melindungi orang dengan kategori yang rentan, termasuk didalamnya masyarakat adat, mereka yang melaporkan kejahatan, mereka yang menunjukkan oposisi politik terhadap geng partai politik, serta perempuan dan anak perempuan yang menantang machismo bercokol atau patriarki(Gellman, 2020). Salah seorang feminis dan aktivis perempuan, Morena Herrera menyatakan bahwa seperti terdapat izin sosial di El Salvador untuk melakukan tindakan kekerasan bahkan pembunuhan terhadap perempuan. Ketika alasan untuk menganiaya, menghina, dan mengendalikan perempuan telah dapat diterima, para 
laki-laki kemudian tumbuh dengan keyakinan akan gagasan bahwa mereka dapat mendominasi pasangan perempuan mereka baik itu pacar ataupun istri mereka.

Dominasi ini bahkan pada saat tertentu dapat memberi perempuan izin untuk mengakhiri hidupnya. Namun, tidak semua perempuan bertindak atas izin tersebut, sehingga laki-laki dapat membunuh perempuan karena mereka (laki-laki) percaya bahwa laki-laki dapat membunuh perempuan (Donovan, 2019). Dalam sebuah laporan Viceland mengungkapkan salah satu pengakuan dari Polisi Wanita El Salvador yang mendapatkan tugas untuk menangani kasus-kasus kekerasan terhadap perempuan sejak diberlakukannya sebuah unit khusus di Kepolisian Nasional El Salvador pada tahun 2012 pernah menangani dan mengirimkan rekan sesama polisinya yang laki-laki ke penjara.

Hal tersebut dikarenakan mereka melakukan tindakan kekerasan terhadap istrinya. Terdapat dindakan perlawanan dari para pelaku, tetapi hal tersebutlah yang menjadi alasan mengapa kepolisian membentuk unit khusus untuk mencegah terjadinya kasus-kasus tindakan kekerasan terhadap perempuan yang selanjutnya dapat meningkat menjadi pembunuhan. Masih dalam laporan yang sama, seorang pengacara dan aktivis perempuan dari ORMUSA (Organización de Mujeres Salvadoreñas por la Paz - NGO di EI Salvador yang fokus pada isu-isu kesetaraan gender dan penghapusan kekerasan terhadap perempuan) Silvia Juarez mengatakan bahwa "ketika kami melihat penyebab mengapa perempuan akan kehilangan hidup mereka di negara ini (El Salvador), coba lihatlah alasan-alasan ini (menikah, ingin bercerai, mau mengakhiri sebuah hubungan); itu semua bukanlah alasan mengapa laki-laki ingin mati".

Ketika terdapat dua orang dihakimi dalam masyarakat dengan standar ganda, yang terjadi adalah diskriminasi dan ketika diskriminasi berakhir dengan kematian dalam sebuah kekerasan ekstrem, maka EI Salvador telah melakukan kejahatan rasial. Dari hal tersebut eskalasi femicide patut diamati sebagai sebuah krisis global namun menjadi epidemi di El Salvador karena "budaya kekerasan" telah menjelma ke dalam alam bawah sadar masyarakatnya yang patriarkis. Perempuan dan anak perempuan akhirnya menjadi korban keganasan budaya tersebut dimana negara pun turut melegitimasi atau membenarkan tindakan kekerasan yang terjadi melalui impunitas kepada pelaku kekerasan terhadap perempuan dan anak perempuan.

\section{FENOMENA FEMICIDE DAN KEKERASAN DI EL SALVADOR}

Konsepsi mengenai femicide muncul dipermukaan dalam sebuah prosiding pada the First International Tribunal on Crimes against Women di Brussels, Belgia pada Meret 1976 oleh Diana E. H. Russell. Russell memberikan pemaknaan pada femicide sebagai sebuah proses mengonseptualisasikan suatu fenomena pembunuhan perempuan melalui identifikasi sirkumstansi kematian dan hubungan yang melekat antara penyintas (perempuan) dengan pembunuh (laki-laki) (Corradi et al., 2016). Kemudian dengan semakin berkembangnya penelitian yang mengkaji femicide ini semakin memperluas dan memberikan perbaikan dalam pemahaman hingga untuk kebijakan publik yang lebih baik lagi.

Hal tersebut tentu saja mengakibatkan definisi mengenai femicide semakin berkembang di kalangan para aktivis, praktisi dan cendekiawan. Femicide juga memberikan kontribusi untuk mematahkan argumen selama ini yang menyatakan 
bahwa kekerasan berbasiskan gender merupakan permasalahan privat dan personal karena pada kenyataannya permasalahan gender ini memiliki implikasi pada bidang lain, seperti politik, sosial dan budaya. Selain itu, simposium yang membahas tentang femicide juga telah dilaksanakan pada tanggal 26 November 2012 di markas besar PBB di Wina, Austria yang menghasilkan deklarasi berupa Declaration of the Vienna Symposium on Femicide. Hasil dari deklarasi tersebut menyatakan bahwa femicide adalah suatu isu global yang tersajikan secara variatif tentang pembunuhan perempuan dan anak perempuan oleh laki-laki dengan hubungan kekerabatan tertentu.

Fenomena femicide di El Salvador ini dapat terjadi dimanapun dan kapanpun, baik di lingkup domestik (rumah tangga) maupun di ruang publik sehingga kondisi inequality dan insecurity masih berlangsung hingga kini. Berbagai perwujudan atau bentuk dari pembunuhan terkait gender dilazimkan secara sosial dan budaya, sehingga, manifestasi femicide terus diterima, ditoleransi atau dibenarkan — dengan impunitas sebagai "norma" di El Salvador. Disini, femicide menjadi puncak dari segala bentuk kekerasan terhadap perempuan karena saratnya "budaya kekerasan" sebagai imbas perang saudara yang pernah terjadi. Perang saudara terjadi di El Salvador antara tahun 1979 sampai dengan 1992 dimana terdapat sekitar 70.000 orang meninggal dan banyak yang hilang. Pemerintah resmi El Salvador melakukan perlawanan terhadap Frente Farabundo Martí para la Liberación Nacional (FMLN) yang berhaluan kiri (leftish) dengan dukungan Amerika Serikat.

Hal ini sangat lumrah terjadi karena kawasan ini adalah "backyard" Amerika Serikat dan dengan model demokratisasi yang dilakukan secara masif, terlebih dengan berbagai doktrin politik luar negeri Amerika Serikat di era Perang Dingin yang bersifat bipolar. Konflik di negara ini berakhir setelah penandatanganan Chapultepec Peace Accords pada tahun 1992 dan pembentukan Kepolisian Nasional (Policia Nacional Civil: PNC) dibawah pengawasan the United Nations Observer Mission in El Salvador (ONUSAL, 1991-1995). Sementara itu, UN Truth Commision ditujukan untuk menangani kekerasan selama masa perang, kejahatan perang diampuni dan tidak ada perbaikan yang dilakukan selain negara El Salvador ditunjuk sebagai pelaku utama kekerasan melalui "pelembagaan sistematis".

Hal ini dikarenakan kurangnya kecaman dan tindakan untuk menegakkan ketertiban pasca-perang, budaya kekerasan yang direstui negara sangat kuat di EI Salvador(De Jesus \& Hernandes, 2019, p. 3). Pasca konflik, El Salvador ditumbuhi dengan berbagai fenomena sosio-politik yang multidimensional timbul sebagai efek domino. Mulai dari menjamurnya gangs (Maras) sebagai manifestasi dari TOC: transnational organized crime (kejahatan transnasional yang terorganisir), penjualan obat-obatan terlarang atau narkotika, jaringan perdagangan manusia dan obat terlarang secara ilegal, migrasi yang masif terutama mencari suaka ke Amerika Serikat dan proliferasi penggunaan senjata api ringan (Human Rights Council, 2012, pp. 1718).

Pada tahun 2011, Kepolisian Nasional El Salvador (PNC) mengeluarkan laporan keberadaan 246 kelompok geng di negara tersebut dengan estimasi jumlah mencapai 28.130 anggota. Sebanyak 45\% dari jumlah itu berada di San Salvador (ibukota negara) sementara sisanya terletak di kota lainnya seperti La Libertad, Santa Ana, Sonsonate dan San Miguel. Rivalitas dua gangs terbesar di El Salvador yakni Mara Salvatrucha-13 (MS-13) dan Barrio 18 (the $18^{\text {th }}$ Street Gang) yang memiliki 
anggota sekitar 20.000 hingga 60.000 anggota(Musalo, 2018, p. 9). Kepolisian Nasional El Salvador juga melakukan beberapa kebijakan untuk menurunkan angka kriminalitas gangs, salah satunya adalah Iron Fist Plan/Mano Dura (Tangan Besi) sejak awal tahun 2000-an. Namun, kebijakan dengan pendekatan "tough on crime" faktanya semakin meningkatkan kekerasan antara geng dan polisi. Penahanan massal anggota geng menjadi wadah bagi penambahan anggota baru. Kondisi ini malah membuat pertumbuhan gangs semakin meluas dan kepolisian dianggap gagal untuk mengurangi tindak kekerasan dan kejahatan (De Jesus \& Hernandes, 2019, p. 4).

Kekuasaan dan kekuatan gangster di El Salvador yang berpengaruh lebih luas dibandingkan negaranya menjadi pemicu tingginya kasus homicide atau pembunuhan terhadap seseorang dalam bentuk apapun. Homicide bermakna sebagai penghilangan nyawa seseorang (dalam hal ini adalah pembunuhan) dalam bentuk apapun -baik disengaja atau tidak, direncanakan atau tidak, maupun beratensi pada tindakan kriminal atau tidak - yang lebih bersifat netral gender. Homicide di El Salvador turut menyumbangkan kasus-kasus pembunuhan terhadap perempuan terkait gender (gender-related killings of women) yang merupakan bentuk kekerasan paling ekstrem terhadap perempuan (Roth \& Villa, 2012, p. 3).

\section{Female victims of intentional homicide (per 100,000 population)}

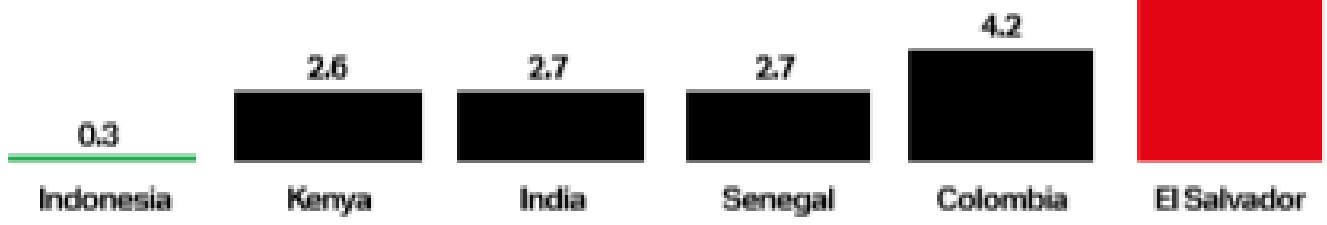

Source: Equal Measures 2030, 2018

Note: UNODC; Colombia, El Salvador, India, Kenya (2016), Indonesia (2014), Senegal (2015)

\section{Gambar 2. Persentase Perempuan yang Terbunuh Akibat "Pembunuhan Secara} Sengaja" (Equal Measures 2030 \& KAPAL Perempuan, 2018)

Homicide yang dialami perempuan di El Salvador bahkan disebabkan hanya karena mereka melakukan kontak dengan geng-geng tersebut (sebagai anggota, mantan anggota ataupun memiliki hubungan dengan anggota geng). Dimana legitimasi budaya kekerasan secara struktural memicu beragam aksi kekerasan terhadap perempuan seperti penculikan, pemerasan, pelecehan seksual, hingga yang paling ekstrem adalah pembunuhan. Rivalitas gangster di El Salvador nyatanya turut menyumbangkan multikompleksitas permasalahan homicide di negara tersebut. Menurut riset dari UNODC, homicide yang menimpa perempuan dan anak perempuan disebut sebagai female homicide. Namun, kejadian tersebut mayoritas dilakukan oleh pasangan intim seperti suami, mantan suami, pacar, mantan pacar sehingga dapat dikategorikan sebagai femicide. 
Instabilitas negara pasca konflik di El Salvador berimplikasi terhadap stigma dunia akan "the land of gangster" sehingga legitimasi budaya machismo dan patriarki yang berakhir dengan femicide semakin menguat. Perempuan Salvadoran yang mengalami pelecehan seksual dan mayoritas melaporkannya ke bagian khusus di Kepolisian Nasional El Salvador (PNC) yang dibentuk sejak 2012 akhirnya tidak lagi mencari bantuan kepada otoritas negara. Polisi tidak menindaklanjuti ke tahap investigasi yang dipengaruhi oleh rendahnya tingkat keyakinan atas informasi tersebut. Selain itu, sistem pengadilan yang tidak efektif menempatkan korban dalam bahaya lebih karena pelaku mengetahui korban pergi ke polisi dan pelaku bebas untuk membalas dendam. Hal ini terjadi karena rekatnya banyak gangster El Salvador sehingga disebut sebagai "the land of gangster" ditambah dengan adanya kewajaran di masyarakat EI Salvador akan "budaya machismo" sejak dilahirkan.

Ada beberapa fenomena homicide di El Salvador yang cukup banyak mendapatkan perhatian internasional, diantaranya: pertama, Karla Turcios, seorang jurnalis yang ditemukan tiga bulan kemudian setelah terbunuh. la dicekik dan mati lemas di jalan dekat tempat dia tinggal. Pasangannya, Mario Huezo, telah membungkus kepala perempuan berusia 33 tahun itu dalam kantong plastik, lalu mencekiknya. Ketika tubuh Karla ditemukan, banyak orang menggambarkan kematian jurnalis sebagai 'titik kritis' dalam mengungkap masalah ini. Pertama, pembunuhan Karla sangat dipublikasikan -tidak hanya mitranya, Mario, muncul di halaman depan surat kabar di El Salvador, outlet Inggris juga meliput berita tersebut. Tidak seperti investigasi femicide sebelumnya, 20 jaksa penuntut bekerja untuk kasus ini. Hanya sepuluh hari kemudian, mereka mengajukan tuntutan terhadap Mario karena femicide yang memburuk dan Mario menyangkal semua tuduhan(Donovan, 2019). Dalam keyakinan bersejarah oleh Hakim El Salvador pada 31 Januari 2020, Mario Huezo didakwa bersalah atas kasus femicide dan dijatuhi hukuman maksimum yaitu 50 tahun penjara(Gellman, 2020).

Kedua, seorang wanita muda -yang meninggalkan El Salvador pada tahun 2014 -ketika berusia 17 tahun, menjelaskan penganiayaan fisik dan seksual yang dilakukan oleh pacarnya yang merupakan anggota geng/gangster. Dia (pacarnya wanita muda) memukulnya sampai memar di seluruh tubuh, menendang kepalanya, dan melemparnya ke dinding. Suatu kali, dia mencekiknya dan memukulinya sampai ke titik dimana "white pants became all red with blood". Dia memaksa perempuan tersebut pindah bersamanya ketika usianya 15 tahun dan melewatkan beberapa hari sekolah karena dia sering mencegahnya pergi ke sekolah. Dia memperkosanya berulang kali dan mengatakan padanya "you are my property" dan dia tidak akan meninggalkannya karena "you are mine". Ketika wanita muda ini mencoba meninggalkannya, pacarnya akan menguntitnya dan mengatakan padanya bahwa dia akan memotongnya menjadi potongan-potongan kecil dan melemparkannya di parit tanah. Setiap kali ibu dari wanita muda ini mencoba membela, dia akan menyerangnya juga, bahkan dia pernah mematahkan hidungnya(The Advocates for Human Rights, 2015).

Ketiga, Graciela Eugenia Ramírez Chávez yang berusia 22 tahun ditemukan tewas di sebuah taman di San Salvador pada bulan Februari. Tunangannya telah menikamnya sebanyak 56 kali pada 13 Februari 2018 dan menjadi headline di El Salvador. Pada kesempatan yang berulang, tetangga memanggil nomor darurat untuk 
melaporkan korban diserang tetapi polisi tidak pernah muncul. Keluarganya merilis foto-foto gaun pengantin yang rencananya akan la pakai, pembunuhnya mengakhiri hidup yang lama dirusak oleh kekerasan. Dia (Graciela) telah melarikan diri ke daerah baru di negara itu dari mantan pasangannya yang telah melecehkannya. Ibunya menceritakan bahwa saat la melapor ke polisi tentang serangan-serangan yang didapatnya, dengan mudahnya mereka menyarankan "take justice into your own hands". Orang-orang berkata tentang kekerasan terhadap perempuan, tetapi saat kamu mencari bantuan, tidak ada yang terjadi(Griffin, 2018).

Kasus-kasus femicide di atas nyatanya masih terjadi meskipun pemerintah El Salvador telah membentuk Kebijakan Nasional untuk Akses Perempuan ke Kehidupan yang Bebas dari Kekerasan (Política Nacional para el acceso de las mujeres a una vida libre de violencia) pada tahun 2012. Disamping berbagai regulasi telah diratifikasi menyangkut penghapusan kekerasan terhadap perempuan yang mengerucut pada fenomena femicide dari tingkat global hingga regional, namun belum optimalnya penegakan keadilan hukum di El Salvador ini bertalian erat dengan budaya yang melekat di masyarakat, yakni machismo.

"El Salvador adalah negara dengan begitu banyak kekerasan geng, begitu banyak kebrutalan, begitu banyak pembunuhan, sehingga tidak ada yang memperhatikan kekerasan terhadap perempuan," kata Almudena Toral, seorang pembuat film yang bepergian dengan reporter Patricia Clarembaux untuk melaporkan situasi untuk TIME dan Univision. Ada 51 pembunuhan untuk setiap 100.000 penduduk pada tahun 2018, tertinggi kedua di Amerika Latin setelah Venezuela yang dilanda krisis. Itu tidak terlihat di lautan kekerasan yang luas ini. Sejak September 2018, Toral dan Clarembaux mengikuti María, seorang wanita yang mencari suaka di AS setelah seumur hidup mengalami kekerasan berbasis gender di EI Salvador. Ketika dia berusia 12 tahun, seorang anggota geng memaksanya menjadi pacarnya. Tiga tahun kemudian, setelah memiliki dua anaknya dan menghadapi pelecehan terus-menerus serta ancaman kematian, María mencoba bunuh diri, hampir menjadi korban kejahatan yang oleh El Salvador disebut "femicide suicide"(Nugent, 2019).

Jaksa Agung El Salvador pada tahun 2018 mengumumkan pembentukan unit baru untuk mengawasi kejahatan terkait kekerasan terhadap perempuan, anak perempuan, kelompok LGBTQI, dan kelompok lain yang rentan terhadap kekerasan. Pihak berwenang tampaknya perlahan-lahan mengatur untuk membalik keadaan. Total kasus femisida turun 20\% antara 2017 dan 2018 menjadi 383 kasus. Kemudian, dalam empat bulan pertama tahun 2019, 30\% lebih sedikit perempuan yang meninggal karena femisida dibandingkan periode yang sama tahun sebelumnya. Tapi pada bulan April, 76 perempuan dan anak perempuan dibunuh hanya karena dianggap perempuan(Nugent, 2019).

\section{KESIMPULAN}

Pemerintah El Salvador sadar sepenuhnya bahwa negaranya sangat berbahaya bagi perempuan dengan tingkat korupsi yang masih tinggi dan ketidakberdayaan pemerintah mengatasi berbagai efek domino dari gangs/Maras terutama rivalitas MS-13 dan Barrio 18. Rivalitas gang di El Salvador secara aktif memberikan efek domino terhadap multikompleksitas masalah lainnya, seperti homicide, femicide, penjualan senjata ilegal, perdagangan manusia, perdagangan 
narkotika dan obat-obatan terlarang, dan lain-lain. Ditambah dengan legitimasi "budaya kekerasan" pasca perang saudara hingga kini berbentuk impunitas.

Hal ini menjadikan perempuan dan anak perempuan termarginalisasi dan menguatnya "budaya diam" bagi mereka yang menerima segala bentuk kekerasan. Puncaknya, fenomena femicide di El Salvador marak dilakukan oleh pasangan intim karena budaya machismo telah merekat erat dalam struktur masyarakat patriarkis di El Salvador. Pemerintah El Salvador sendiri telah membuat aturan hukum secara nasional, lalu menandatangani dan meratifikasi berbagai konvensi baik di tingkat regional hingga global, namun nyatanya belum berdampak secara signifikan terhadap upaya degradasi fenomena femicide. Maka dari itu, diperlukan banyak aktor yang terlibat dalam upaya penghapusan kekerasan terhadap perempuan akan dapat berimplikasi pada degradasi kesenjangan gender (fenomena femicide) dan mereproduksi kesetaraan gender (mengikisnya budaya machismo dan patriarki) melalui pelaksanaan kebijakan (aturan atau regulasi) anti bias gender.

\section{REFERENSI}

Ashari, K. (2015). Kamus Hubungan Internasional. Bandung: Nuansa Cendekia.

Corradi, C., Marcuello-Servós, C., Boira, S., \& Weil, S. (2016). Theories of femicide and their significance for social research. Current Sociology, 64(7), 975-995. https://doi.org/10.1177/0011392115622256

De Jesus, M., \& Hernandes, C. (2019). Generalized Violence as a Threat to Health and Well-Being: A Qualitative Study of Youth Living in Urban Settings in Central America's "Northern Triangle. International Journal of Environmental Research and Public Health, 16(18), 3465. https://doi.org/10.3390/ijerph16183465

Donovan, L. (2019, April 4). Men Kill Women Because They Can: Inside El Salvador's Devastating Femicide Crisis. Elle.Com. Retrieved from https://www.elle.com/uk/life-and-culture/a25626891/el-salvador-femicide-crisis/

Equal Measures 2030, \& KAPAL Perempuan. (2018). Data Driving Change: Introducing the EM2030 SDG Gender Index. Retrieved from https://data.em2030.org/wp-content/uploads/2018/09/EM2030-2018-GlobalReport.pdf

Eriyanti, L. D. (2017). Pemikiran Johan Galtung tentang Kekerasan dalam Perspektif Feminisme. Jurnal Hubungan Internasional, 6(1), 27-37. https://doi.org/https://doi.org/https://doi.org/10.18196/hi.61102

Galtung, J. (1996). Peace by Peaceful Means: Peace and Conflict, Development and Civilization. London: SAGE Publications.

Gellman, M. (2020, February 6). Landmark Femicide Case Fails to Fix El Salvador's Patriarchy. The Globe Post. Retrieved from https://theglobepost.com/2020/02/06/femicides-el-salvador/

Griffin, J. (2018, June 6). "Police never turned up": El Salvador's devastating epidemic of femicide. The Guardian. Retrieved from https://www.theguardian.com/globaldevelopment/2018/jun/06/el-salvador-devastating-epidemic-femicide

Gunadha, R. (2018, August 11). Femicide, Mereka Dibunuh karena Berkelamin Perempuan. Suara.Com. Retrieved from https://www.suara.com/news/2018/08/11/200117/femicide-mereka-dibunuhkarena-berkelamin-perempuan

Human Rights Council. (2012). Report of the Special Rapporteur on Violence against 
Women, Its Causes and Consequences: Rashida Manjoo, United Nations General Assembly A/HRC/20/16.

Igarapé Institute. (2017). Latin America can Reduce Homicide by 50 Percent in 10 years. Retrieved from https://igarape.org.br/wp-content/uploads/2017/08/11-082017-Campanha-Instinto-de-Vida-EN.pdf

Makarim, M. (2012). Memaknai "Kekerasan". Lembaga Studi dan Advokasi Masyarakat.

Morales, G. (2020, February 27). What is femicide? Retrieved from https://www.eluniversal.com.mx/english/what-femicide

Musalo, K. (2018). El Salvador - A Peace Worse than War: Violence, Gender and a Failed Legal Response. Yale Journal of Law \& Feminism, 30(1), 3-97. https://digitalcommons.law.yale.edu/yjlf/vol30/iss1/1

Nugent, C. (2019, May 14). Violence Against Women in El Salvador Is Driving Them to Suicide - Or to the U.S. Border. TIME. Retrieved from https://time.com/5582894/gender-violence-women-el-salvador/

Pinelo, A. L. (2015). A Theoretical Approach to the Concept of Femicide/ Feminicide [Universiteit Utrecht]. Retrieved from http://dspace.library.uu.nl/handle/1874/320468

Prieto-Carrón, M., Thomson, M., \& Macdonald, M. (2007). No More Killings! Women Respond to Femicides in Central America. Gender and Development, 15(1), 2540. http://www.jstor.org/stable/20461179

Radford, J., \& Russell, D. E. H. (1992). Femicide: The Politics of Woman Killing. New York: Twayne Publisher.

Roth, F., \& Villa, A. V. (Eds.). (2012). Defining "femicide" and "feminicide." In Latin American Model Protocol for the investigation of gender-related killings of Women (Femicide/Feminicide). OHCHR \& UN Women. Retrieved from https://eurogender.eige.europa.eu/system/files/eventsfiles/latin_american_protocol_for_investigation_of_femicide.pdf

The Advocates for Human Rights. (2015). El Salvador: Submission to the Human Rights Committee for the 114th Session. Retrieved from https://tbinternet.ohchr.org/Treaties/CCPR/Shared Documents/SLV/INT_CCPR_ICS_SLV_20226_E.docx

United Nations Office on Drugs and Crimes. (2012, November 26). Symposium on Femicide: A Global Issue that Demands Action! Retrieved from https://www.unodc.org/unodc/en/ngos/DCN5-Symposium-on-femicide-a-globalissue-that-demands-action.html

Viceland. (2016). The Violent Machismo Culture in El Salvador: WOMAN (Exclusive) [Video]. Youtube. Retrieved from https://www.youtube.com/watch?v=NUaQD73KM0Q

Windhu, I. M. (1992). Kekuasaaan dan Kekerasan Menurut Johan Galtung. Yogyakarta: Percetakan Kanisius. 